Institute of Molecular Genetics, even sees a benefit to science - if the embargo does not continue for too long. A group from the institute, now working in the United States, was among the first to develop an automated DNA chip that improves sequencing, and Glisin believes that a major shakeup may open the door to the type of evaluation and peer review common in the West.

Researchers are doing what they can to blunt the impact of the embargo: Glisin admits to having driven his ice-buckets to Trieste, Italy, via Hungary and Austria, to sustain a collaboration. But the best hope for Serbian science is that the peaceful protests of researchers, students and others may help to end the political stalemate and the UN sanctions.

Alison Abbott

\section{German states offer to trade power for money}

Munich. Germany's 16 states want the federal government to pick up a higher percentage of the cost of research, leaving them with more money for academic reform.

Research funding is shared equally by the federal and regional governments. All other aspects of higher education are the sole responsibility of the individual states. But the recent crisis of university overcrowding has forced the states to look for money from other sources to implement urgent reforms (see Nature 357, 349; 1992).

For the first time in more than 25 years, the states are willing to reduce their power in Germany's overall research planning in exchange for the cash they need. Nevertheless, their preference is for the federal government to reallocate tax revenues to give them enough money to cope with both higher education and research.

That proposal has been criticized since it was made at last month's annual meeting of regional presidents. The federal ministry for education and research says that it cannot afford to spend more; earlier this month, its own request for an annual budget of DM2 billion (US\$1.35 billion) was rejected by the finance ministry. Its budget will instead be frozen at DM1.6 billion.

The Deutsche Forschung Gemeinschaft, the federal agency that administers research grants to universities throughout Germany, has warned that changing the balance of local and federal power over funding could damage research. But the alternative changing the way in which tax revenues are distributed - seems unlikely in Germany's current economic crisis.

The state governments hope to discuss their proposal at an unprecedented meeting that the German chancellor, Helmut Kohl, agreed two months ago to hold. State officials are still waiting for Kohl to announce a date.

Alison Abbott

\title{
Japanese report shows cracks in predicting earthquakes
}

Tokyo. Japan's earthquake prediction scientists have admitted for the first time that there is a huge gap between their public optimism and the realities of research.

Any mention of shortcomings in a 30-year effort to find signs of imminent earthquakes is tucked away in a 72-page review of Japan's earthquake prediction programme released on 17 July by the Ministry of Education, Science and Culture (MESC) that is devoted to a detailed account of the observations under way. But there are also a few lines of criticism, after outsiders were used for the first time to assess the project.

Japan has invested about a billion dollars in equipment for earthquake prediction. About 500 researchers work in the programme, receiving almost $¥ 7$ billion (US\$56 million) a year in government support in addition to their salaries. This makes the Japanese programme the longest, largest and most comprehensive effort in the world.

But the programme cannot point to any real successes, and there have been some embarrassing failures. For example, in June and July 1989, earthquake swarms around the city of Ito on the Izu peninsula south of Tokyo were for weeks attributed to plate tectonic movement. Although local fishermen had reported discoloration of the sea and dead fish on the surface, scientists did not realize that a major submarine volcanic eruption was imminent until a few hours before it occurred. Even so, most Japanese remain convinced that the next major earthquake in the seismically active region south of Tokyo can be predicted, and researchers encourage that belief.

The present review was carried out by an eight-man working group of the earthquake prediction subcommittee of the Geodetic Council of Japan, an advisory body to MESC. All the members have worked on earthquake prediction for years.

However, as a result of severe criticism of the programme by scientists such as Robert Geller of Tokyo University, the work of the committee was reviewed by six outsiders. They included Masuo Ida, a former MESC official and a vocal critic of the programme; Saburo Nagakura, president of the Graduate University for Advanced Studies and an influential figure within the education ministry; and the heads of the volcanological and seismological societies of Japan (see Nature 356, 464; 1992).

Although the comments of the outside reviewers have not been made public, scientists who attended hearings in May say they were "very critical" of the programme. One Tokyo University professor says they were "perhaps too critical". Nagakura is said to have questioned both the quality of past reviews and the premise that earthquake prediction is possible.

The criticisms are not immediately apparent in the revised review released on 17 July. But page 70 of the 72-page report admits that although great improvements have been made in the network for observing anomalous phenomena associated with earthquakes such as changes in ground water levels and radon levels and fluctuations in the Earth's magnetic and electric fields, "there are many cases in which such anomalous observations cannot be objectively identified as earthquake precursors". In the absence of any successful observations, says Geller, this is the closest that Japan's earthquake prediction community has come to agreeing with its colleagues elsewhere that earthquake prediction is not possible.

On the next page, the report offers even more self-criticism. "Society's expectations for earthquake prediction are high", it states, "but we cannot deny that there is a considerable gap between society's expectations and the present state of earthquake prediction".

The report concludes by saying that the whole system of review of the programme is now "under study". In the autumn, a committee will be formed to plan the next fiveyear programme, which begins in 1994. All eyes are on MESC and the Geodetic Council to see if outsiders, perhaps even non-Japanese, will be included.

But critics are sceptical as to whether drastic changes will be made in the programme. Outside researchers complain that it takes too long to obtain data from Japan's observation networks, and that the only way to get data quickly is to become coauthors with members of the earthquake prediction community. Last month, for example, the Earthquake Research Institute of Tokyo University released hypocentre and travel time data recorded in 1986 on magnetic tapes.

The report calls for greater interaction and exchange of data with Earth scientists involved in basic research, but adds that the volume of data makes this impossible at present. Geller, however, points out that researchers from the United States, France and Britain have long enjoyed comparatively quick access to such data. Reform cannot begin, he says, until there is a fundamental change in the attitude of Japan's earthquake prediction researchers.

David Swinbanks 